Institute of $\mathbf{F}_{\text {ood and }} \mathbf{A}_{\text {gricultural }} \mathbf{S}_{\text {ciences }}$

\title{
2003 Handbook of Employment Regulations Affecting Florida Farm Employers and Workers: Introduction ${ }^{1}$
}

\author{
Leo C. Polopolus, Michael T. Olexa, Fritz Roka, and Carol Fountain ${ }^{2}$
}

This handbook is intended to provide a convenient reference to the major provisions of the several state and federal regulations that affect farm employers and employees. It reflects state and federal laws as of July 1, 2002, only as they apply to farm workers and not to workers considered non-agricultural. Its purpose is simply to focus employers and employees on the fundamental provisions of the laws which govern their relationships.

For the purposes of this handbook, the definition of "farmworker" is taken from the United States Department of Labors Occupational Outlook Handbook for 2002-03. A farm or agricultural worker is one who is paid for work performed on crop and/or livestock operations. Those individuals who perform veterinary and landscaping services are not considered farmworkers according to the United States Department of Labor occupational definition. Farmworkers may work for piece rates or be paid an hourly wage. Farmworkers may work part-time, seasonally, or full-time. They may perform manual labor, operate equipment, or supervise other farm personnel.

Thus, this handbook does not and should not substitute for specific technical advice from responsible state and federal agencies, knowledgeable grower associations, legal agencies, or other experts in the agricultural labor law field. There is also no attempt to cover all aspects of specialized agricultural labor and safety law (e.g., logging and/or forestry operations).

1. This is EDIS document FE390, a publication of the Department of Food and Resource Economics, Florida Cooperative Extension Service, Institute of Food and Agricultural Sciences, University of Florida, Gainesville, FL. Published July 2003. This information is included in Circular 1200, Handbook of Employment Regulations Affecting Florida Farm Employers and Workers. First published February 1992 as Circular 1043 . Revised December 2002 as Circular 1200. Please visit the EDIS website at http://edis.ifas.ufl.edu.

2. Leo C. Polopolus, Professor Emeritus, Department of Food and Resource Economics, University of Florida, Gainesville, FL; Michael T. Olexa, Professor, Department of Food and Resource Economics, University of Florida, Gainesville, FL; Fritz Roka, Associate Professor, Department of Food and Resource Economics, Southwest Florida Research and Education Center, Immokalee, FL; and Carol Fountain, Assistant Editor, Department of Food and Resource Economics, University of Florida, Gainesville, FL; Florida Cooperative Extension Service, Institute of Food and Agricultural Sciences, University of Florida, Gainesville, FL.

This document is designed to provide accurate, current, and authoritative information on the subject. However, since the laws, administrative rulings, and court decisions on which it is based are subject to constant revision, portions of this publication could become outdated at any time. This publication is distributed with the understanding that the authors are not engaged in rendering legal or other professional advice, and the information contained herein should not be regarded as a substitute for professional advice. For these reasons, the utilization of these materials by any person constitutes an agreement to hold harmless the authors, the Institute of Food and Agricultural Sciences, and the University of Florida for any liability claims, damages, or expenses that may be incurred by any person as a result of reference to or reliance on the information contained in this publication.

The Institute of Food and Agricultural Sciences is an equal opportunity/affirmative action employer authorized to provide research, educational information and other services only to individuals and institutions that function without regard to race, color, sex, age, handicap, or national origin. For information on obtaining other extension publications, contact your county Cooperative Extension Service office. Florida Cooperative Extension Service/Institute of Food and Agricultural Sciences/University of Florida/Christine Taylor Waddill, Dean. 
This handbook is distributed with the understanding that the authors are not engaged in rendering legal or other professional advice and the information contained in this handbook should not be regarded or relied upon as a substitute for professional advice. This handbook is not all-inclusive in providing information to achieve compliance with laws and regulations governing the practice of agriculture. For these reasons, the use of these materials by any person constitutes an agreement to hold harmless the authors, contributors to the handbook, the Institute of Food and Agricultural Sciences, and the University of Florida for any liability claims, damages, or expenses that may be incurred by any person as a result of reference to or reliance on the information contained in this handbook. 